\title{
FAKTOR-FAKTOR YANG BERHUBUNGAN DENGAN APLIKASI MOTORISASI PENANGKAPAN (STUDI KASUS DI KECAMATAN SALAHUTU KABUPATEN MALUKU TENGAH PROPINSI MALUKU)
}

\author{
Franklin Syauta ${ }^{*}$
}

\begin{abstract}
ABSTRAK
Nelayan akan dapat mengaplikasikan motorisasi penangkapan bila mereka mempunyai kemauan, kemampuan dan kesempatan. Kemauan, kemampuan dan kesempatan akan dimiliki nelayan. bila didukung oleh faktor internal dan faktor eksternal. Hasil yang diperoleh nelayan di Kecamatan Salahutu setelah menggunakan motorisasi tidak terlepas dari pengaruh faktor internal dan faktor eksternal tersebut. Faktor internal dan faktor eksternal yang berhubungan dengan aplikasi motorisasi penangkapan di Kecamatan Salahutu adalah: umur, pencapaian pendidikan formal. keikutsertaan dalam kursus dan pelatihan, pengalaman menangkap ikan, ukuran keluarga, motif usaha, interaksi dengan sumber informasi, dukungan sarana dan prasarana serta keikutsertaan dalam kegiatan pembinaan nelayan.
\end{abstract}

ABSTRACT: Factors affecting the application of motorized boat (a case study in Salahutu District, Central Maluku Regency, Indonesia). By: Franklin Syauta.

The participatory approach believes that human being will be able to overcome his problem if there are supporting circumstances. Fishermen will motorize their fishing equipment if they have willingness, the skill, and the opportunity, which depend on internal and external factors. The achievement of fishermen of Salahutu District in motorizing their boat is inevidably affected by the internal and external factors.

The internal and external factors expected to have a correlation with the application of motorized boat are age, formal educational achievement, attendances in cources and trainings, fishing experiences, size of family, motivation, access to source of information, infrastructure support, and participation in extension artivities. The application of motorized boats have some effects on fishermen income.

KEYWORDS: technology adoption, motorized boat, Central Maluku Regency.

\section{PENDAHULUAN}

Maluku Tengah adalah satu dari lima kabupaten di Propinsi Maluku dengan potensi perikanan sebesar 53.157 ton/tahun. Sebagian besar penduduk Maluku tinggal tersebar di kabupaten ini, yaitu sejumlah 667.332 jiwa atau $31,79 \%$ (Biro Pusat Statistik, 1997). Kegiatan penangkapan ikan laut, termasuk jenis usaha perikanan rakyat yang berkembang dengan baik pada masyarakat di pesisir pantai.

Pengembangan usaha penangkapan dilakukan melalui peningkatan produktivitas usaha perikanan tradisional, menggunakan peralatan yang lebih maju dan teknologi tepat guna, serta memacu perkembangan perikanan lepas pantai dan samudera. Pemanfaatan teknologi motorisasi penangkapan ikan laut, merupakan salah satu kebijaksanaan pemerintah daerah untuk meningkatkan pendapatan dan kesejahteraan nelayan di Kabupaten Maluku Tengah. Hasilnya terbukti melalui keberhasilan nelayan di wilayah ini mengaplikasikan motorisasi penangkapan, dibandingkan nelayan wilayah lain dengan bentuk usaha yang sama.

Keberhasilan nelayan Kecamatan Salahutu mengaplikasikan motorisasi penangkapan ikan laut, tidak lepas dari pengaruh faktor internal dan faktor eksternal. Sejauh mana nelayan mengaplikasikan motorisasi penangkapan, bagaimana hubungan antara faktor internal dan faktor eksternal nelayan dengan aplikasi moto-

\footnotetext{
Dosen pada Fakultas Perikanan, Univ. Pattimura, Ambon
} 
risasi penangkapan, serta bagaimana hubungan antara aplikasi motorisasi penangkapan pendapatan nelayan merupakan aspek yang ingin diketahui melalui penelitian ini.

\section{BAHAN DAN ME'TODE}

\section{Kerangka Analisis}

Penelitian ini berdasarkan hipotesis bahwa terdapat hubungan antara faktor internal dan faktor eksternal nelayan dengan aplikasi motorisasi serta adanya hubungan antara aplikasi motorisasi dengan pendapatan nelayan (Gambar 1).

\section{Pengumpulan dan Analisis Data}

Populasi penelitian adalah nelayan penggarap yang aktif mengaplikasikan motorisasi penang kapan ikan laut di Kecamatan Salahutu selama tiga tahun terakhir. Sehanyak 180 responden diambil dari 890 nelayan dari tiga desa, yaitu: Waai 75 responden (dari 365 nelayan). Tulehu 100 responden (dari 500 nelayan) dan Liang 5 responden (dari 25 nelayan). Nelayan tanase (pemimpin operasi) dan lobe (penanggung jawab penangkapan) seluruhnya diambil sebagai responden, yakni dua orang setiap unit kapal bermotor atau 72 orang dari 36 unit kapal bermotor. Responden masnait (anak buah kapal) ditentukan dengan acak sederhana (Black \& Champion, 1992).

Lama penelitian dua belas minggu, dari Juli 1996 hingga September 1996. Data dikumpulkan melalui wawancara langsung menggunakan kuesioner. Sebagai pembanding, data juga diambil dari tokoh masyarakat, pimpinan formal dan informal di tingkat desa, kecamatan serta pihak-pihak yang berhubungan langsung dengan penelitian.

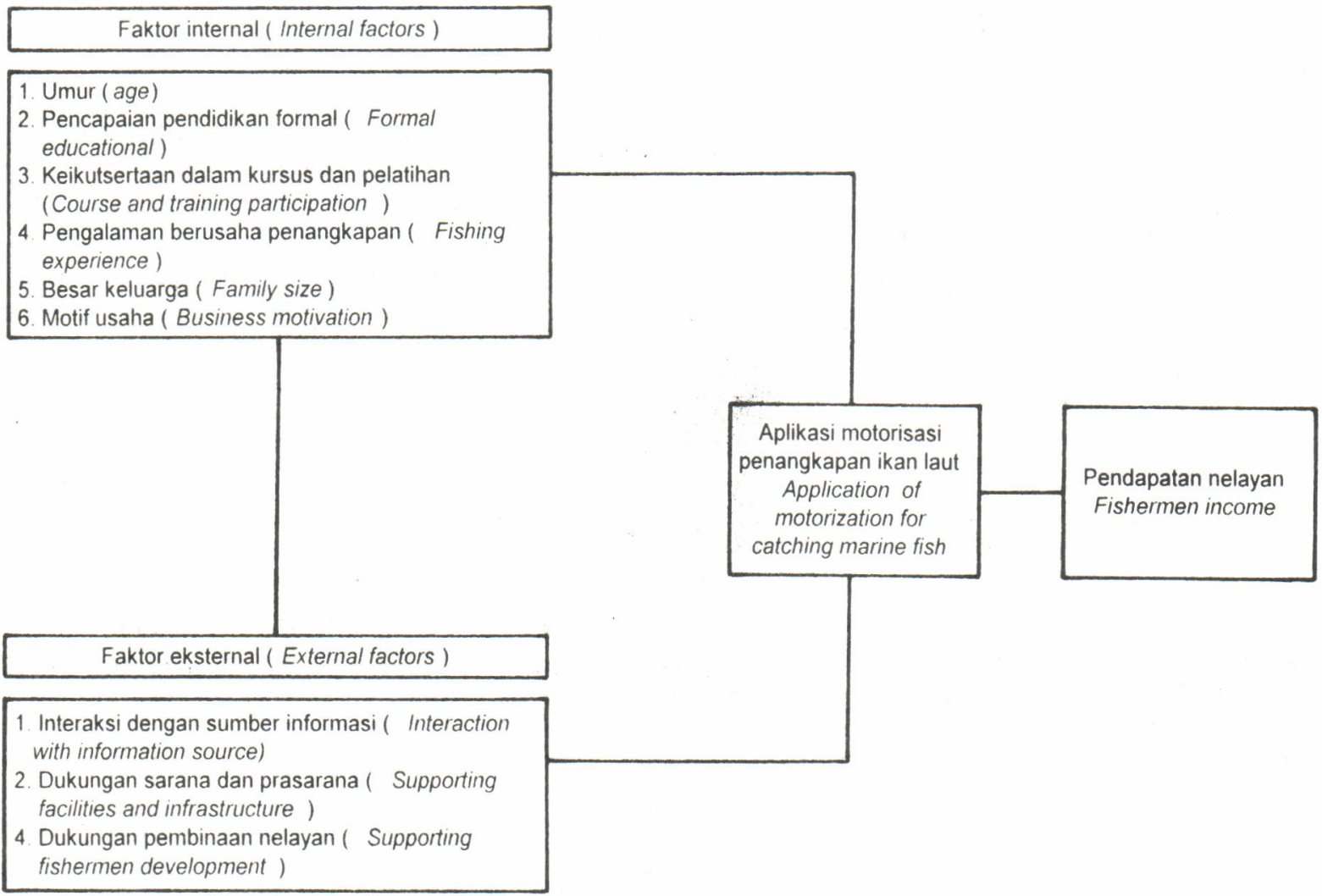

Gambar 1. Model hubungan antara faktor internal dan faktor eksternal dengan aplikasi motorisasi penangkapan dan pendapatan nelayan.

Figure 1. Relation model between internal and external factors with the motorization application and fishermen income. 
Keadaan faktor internal dan faktor eksternal nelayan dijelaskan melalui teknik elaborasi atau tabulasi silang (Singarimbun \& Effendi, 1989). Hubungan faktor internal dan faktor eksternal dengan aplikasi motorisasi penangkapan di analisis berdasarkan Uji Korelasi Peringkat Spearman (Walpole, 1992):

$$
r_{s}=1 \frac{6}{n\left(n^{2}-1\right)} \sum_{i i}^{n} d_{i}^{2}
$$

Keterangan:

$r_{s}$ : koefisien korelasi peringkat Spearman

$d_{i}$ : selisih antara peringkat bagi $X_{i}$ dan $Y_{i}$

$\mathrm{n}$ : banyaknya pasangan data

\section{HASIL DAN PEMBAHASAN}

\section{Aplikasi Motorisasi Penangkapan Ikan Laut}

Hasil analisis menunjukkan bahwa sebagian besar $(51 \%)$ responden telah mencapai kategori tinggi dalam mengaplikasikan motorisasi penangkapan di Kecamatan Salahutu (Tabel 1).

Tingkat aplikasi motorisasi ditentukan berdasarkan peningkatan dan pengembangan usaha penangkapan ikan tradisional, melingkupi ke- satuan dari aspek kemampuan kapal bermotor, kemampuan nelayan, hasil yang dicapai dan kepuasan nelayan terhadap sistem manajerial yang diterapkan pengusaha.

Tingginya aplikasi dilihat dari luasnya kawasan penangkapan, banyaknya trip dalam sehari, daya tampung hasil, fasilitas penyim. panan yang memadai di kapal, efisiensi dan efektivitas penggunaan waktu dan tenaga di laut, jumlah awak yang memadai saat operasi, pem. bagian tanggung jawab di atas kapal, penguasaan teknik melaut, kemampuan interaksi antara awak saat penangkapan, kepuasan responden terhadap manajemen yang diterapkan oleh pengusaha menyangkut sistem bagi hasil. kesejahteraan awak dan interaksi antara peng. usaha dan awak.

\section{Keadaan dan Hubungan Faktor Internal dan Faktor Eksternal Nelayan dengan Aplikasi Motorisasi Penangkapan.}

Hasil analisis keadaan faktor internal dan faktor eksternal nelayan yang mengaplikasikan motorisasi penangkapan dapat dilihat pada Tabel 2 , sedangkan hasil analisis hubungan antara faktor internal dan faktor eksternal nelayan dengan aplikasi motorisasi penangkapan (peubah dinyatakan berhubungan bila nilai $r_{s}$ peubah lebih besar dari nilai kritik $r_{8}$ pada $P=0,05$ ) dapat dilihat pada Tabel 3.

Tabel 1. Distribusi frekuensi tingkat aplikasi motorisasi penangkapan.

Table 1. Frequensi distribution of the motorized boat aplication level.

\begin{tabular}{lcc}
\hline $\begin{array}{c}\text { Kategori aplikasi motorisasi } \\
\text { penangkapan ikan laut } \\
\text { Category of motorization } \\
\text { application of marine fish }\end{array}$ & $\begin{array}{c}\text { Jumlah responden (orang) } \\
\text { Number of respondent } \\
\text { (person) }\end{array}$ & $\begin{array}{c}\text { Persentase responden }(\%) \\
\text { Percentage of respondent }(\%)\end{array}$ \\
\hline Rendah (low) & 16 & 9 \\
Sedang (medium) & 72 & 40 \\
Tinggi (high) & 92 & 51 \\
\hline Jumlah (total) & 180 & 100 \\
\hline
\end{tabular}


Tabel 2. Distribusi responden menurut analisis tabulasi silang antara faktor internal dan faktor eksternal dengan tingkat aplikasi motorisasi penangkapan.

Table 2. Respondent distribution by cross-labulation analysis of the motorization application level on internal and external factors of the respondent.

\begin{tabular}{|c|c|c|c|c|c|}
\hline \multirow{2}{*}{$\begin{array}{l}\text { Faktor internal } \\
\text { dan faktor } \\
\text { eksternal } \\
\text { Internal and } \\
\text { external factors }\end{array}$} & \multirow[t]{2}{*}{$\begin{array}{l}\text { Kategori } \\
\text { Catrgory }\end{array}$} & \multicolumn{3}{|c|}{$\begin{array}{l}\text { Kategori aplikasi motorisasi }(\%) \\
\text { Motorization application category }(\%)\end{array}$} & \multirow{2}{*}{$\begin{array}{c}\text { Persentase } \\
\text { responden } \\
\text { Percentage o } \\
\text { respondent }\end{array}$} \\
\hline & & $\begin{array}{l}\text { Rendah } \\
\text { Lou! }\end{array}$ & $\begin{array}{l}\text { Sedang } \\
\text { Medium }\end{array}$ & $\begin{array}{c}\text { 'Tinggi } \\
\text { High }\end{array}$ & \\
\hline \multirow{5}{*}{$\begin{array}{l}\text { Umur } \\
\text { Agre }\end{array}$} & Kurang produktil (<30 tahun) & 4 & 1.3 & 3 & 20 \\
\hline & Less productive $(<30$ years) & & & & \\
\hline & $\begin{array}{l}\text { Sangat produktif (30-40 tahen) } \\
\text { Most productionly (30-40 vears) }\end{array}$ & 3 & 18 & 26 & 47 \\
\hline & $\begin{array}{l}\text { Produktif( }>40 \text { iahun) } \\
\text { Productire }(>40 \text { years) }\end{array}$ & 1 & 10 & 22 & 33 \\
\hline & & 8 & 41 & .51 & 100 \\
\hline \multirow{3}{*}{$\begin{array}{l}\text { Poncapaian pendi- } \\
\text { dikan formal (PPP) } \\
\text { Formal education }\end{array}$} & Rendal, $<7$ tahum (l,ow. $<7$ years) & 5 & 16 & 32 & $\overline{53}$ \\
\hline & Sedang. 7-9 tahun (Medium, 7-9 years) & 2 & 1.3 & 15 & 30 \\
\hline & Tinggei. > 12 tahun (High, > 12 years) & 1 & 12 & 4 & 17 \\
\hline & & 8 & 41 & 51 & 100 \\
\hline \multirow{5}{*}{$\begin{array}{l}\text { Keikutscrtaan } \\
\text { dalam kursus dan } \\
\text { pelatihan } \\
\text { course \& trammg } \\
\text { parlicipaton }\end{array}$} & Tidak ikut serta (No participate) & 7 & 36 & 39 & 82 \\
\hline & Ikut kerta (participatr) & 1 & 5 & 12 & 18 \\
\hline & & & & & \\
\hline & & & & & \\
\hline & & 8 & 41 & 51 & 100 \\
\hline \multirow{4}{*}{$\begin{array}{l}\text { Pengalaman ber- } \\
\text { usaha penangkapan } \\
\text { Fishmg experionco }\end{array}$} & Rendah. $<10$ tahun (Low $<10$ years) & 5 & 25 & 1 & 3.1 \\
\hline & Sedang. 10-15 tahun (Medium, 10-15 years) & 2 & (i) & 10) & 18 \\
\hline & Tinggi, $>15$ tahun (High, $>15$ years) & 1 & 10 & 37. & 48 \\
\hline & & 8 & 41 & 51 & 100 \\
\hline \multirow{4}{*}{$\begin{array}{l}\text { Besar keluarga } \\
\text { Family size }\end{array}$} & Kecil, <5 orang (lithl', < 5 persons) & 6 & 22 & 1.5 & 42 \\
\hline & Sedang, 5-6 orang (Medium, 5-6 persons) & 1 & 18 & 31 & 5.1 \\
\hline & Besar. $>6$ orang (Big, $>$ G persons: $)$ & 1 & 1. & 5 & 7 \\
\hline & & 8 & 41 & 51 & 180 \\
\hline Motif usaha & Rendah / Lou $(<9)$ & 4 & 4 & 1 & 9 \\
\hline Bussiness & Soding / Medium (9)-1.1) & 3 & 17 & 12 & 32 \\
\hline \multirow[t]{2}{*}{ motivation } & Tinggi / High $(>14)$ & 1 & 20 & 38 & 59 \\
\hline & & 8 & 41. & 51 & 100 \\
\hline \multirow{4}{*}{$\begin{array}{l}\text { Interaksi dengan } \\
\text { sumber informasi } \\
\text { Interartion by } \\
\text { information source }\end{array}$} & Rendah / Lou' $(<14)$ & 4 & 7 & 1 & 12 \\
\hline & Sedang / Medium (1.1-22) & 3 & 23 & 22 & 48 \\
\hline & 'linggi / /ligh (> 22) & 1 & 11 & 28 & 40 \\
\hline & & 8 & 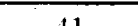 & -1 & 100 \\
\hline \multirow{5}{*}{$\begin{array}{l}\text { Dukungan sarana } \\
\text { dan prasamana } \\
\text { Supportmg fasilities } \\
\text { \& infrastructure }\end{array}$} & Rendah / Low $<15)$ & 0 & & 1 & \\
\hline & Sedang / Medium (15.25) & 2 & $\frac{2}{17}$ & 27 & 46 \\
\hline & Tinggi / High ( $>25)$ & (j) & 22 & 23 . & 51 \\
\hline & & & & & \\
\hline & & 8 & 41 & 51 & 100 \\
\hline \multirow{5}{*}{$\begin{array}{l}\text { Dukungan } \\
\text { pembinatan nelayan } \\
\text { Supporting fisher. } \\
\text { mon development }\end{array}$} & Reudah / Low (<5 kali) & 6 & 26 & 22 & .54 \\
\hline & Sedang / Medium (5-7 kali) & 1 & 12 & 19 & 32 \\
\hline & Tingrgi / High (> $7 \mathrm{kali})$ & 1 & 3 & 10) & 11 \\
\hline & & & & & \\
\hline & & 8 & 41 & 51 & 100 \\
\hline
\end{tabular}


Tabel 3. Matriks koefisien korelasi peringkat Spearman antara faktor intornal dan faktor eksternal dengan aplikasi motorisasi penangkapan.

Table 3. Sprarman rank correlation coefficients between internal and external factors of the respondent. the molorization application level.

\begin{tabular}{|c|c|c|c|c|c|c|c|c|c|}
\hline & Umr & $\mathrm{PPF}$ & KKP & PBP & $\mathrm{BK}$ & $\mathrm{MU}$ & $\mid \mathbf{S I}$ & DSP & DPN \\
\hline Umr & 1.0000000 & & & & & & & & \\
\hline $\mathrm{PPF}$ & 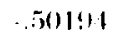 & 1.0000000 & & & & & & & \\
\hline KKP & 2606.1 & . 17185 & 1.000000 & & & & & & \\
\hline PBP' & $8106 i 7$ & .40557 & 2.319012 & 1.000000 & & & & & \\
\hline$B K$ & 5492.4 & $.315 .1 ! 1$ & .31215 & .52298 & 1.000000 & & & & \\
\hline MU & 11887 & .47951 & .16265 & .17852 & .02401 & 1.000000 & & & \\
\hline$|S|$ & .783911 & -.263 .301 & $233(15)$ & $7 ! 1085$ & .18069 & .36921 & 1.00000 & & \\
\hline DSP & $.29145,1$ & .336222 & .20351 & 35!90: & -.307\%? & .07458 & .17522 & 1.00000 & \\
\hline DPN & $.432 \div 8$ & $\cdot .20480$ & .165 .49 & filfigi.1 & .23471 & .12552 & .41524 & .28138 & 1.00000 \\
\hline$A p l$ & 51344 & -.23177 & .27281 & 63570 & .33282 & .34008 & .58679 & .12035 & .237611 \\
\hline \multirow[t]{2}{*}{ Pndpt } & .13800 & $\cdot .34451$ & .506009 & .57221 & . 11 (6icis) & $.16: 183$ & $.53 !) 23$ & .32065 & $.20) 131$ \\
\hline & & $A p l$ & Pndpt & & & & & & \\
\hline i & 1 (m)(o) & & & & & & & & \\
\hline Pndpt & (67)tol & 1.1001001 & & & & & & & \\
\hline $\begin{array}{l}\text { CRITI } \\
\text { CRITI } \\
\text { N. } 186\end{array}$ & $\begin{array}{l}\text { VAIUE } \\
\text { VAIUHI }\end{array}$ & $\begin{array}{l}\text { All.,.(05) } \\
\text { All, .05) }\end{array}$ & $\begin{array}{l}.12301 \\
.14630\end{array}$ & & & & & & \\
\hline
\end{tabular}

keterangan (note): singliatan lihat Gambar 1 (abbrevation sec Figure l)

\section{- Umur}

Sebagian besar $(47 \%)$ responden bekerja pada kategori umur kerja sangat produktif. Banyak responden dijumpai pada kategori umur kerja produktif, karena pada usia tersebut ketahanan fisik nelayan mampu menghadapi kondisi alam yang ekstrim, sehingga cenderung lebih banyak beraktivitas dalam kegiatan penangkapan. Aktivitas nelayan dalam kegiatan penangkapan pada umur kerja kurang produktif, cenderung rendah, karena belum siap secara fisik. mental dan rendahnya pengalaman melaut.

Umur nelayan ternyata mempunyai hubungan vang nyata dengan kemampuan mengaplikasikan motorisasi penangkapan. Aktivitas penangkapan cenderung berkurang setelah nelayan memasuki kategori umur kerja produktif (> 40 tahun), karena secara fisik kemampuan menghadapi kondisi alam yang ekstrim mulai menurun. Dengan demikian daya tahan tubuh merupakan faktor penentu, karena pekerjaan menangkap ikan tidak mudah bagi seorang yang belum dewasa dan bagi mereka yang sudah tua. De Cecco (1989) menegaskan bahwa umur seseorang berpengaruh pada kematangan fisik dan emosi.
Umur nelayan juga berhubungan nyata dengan pengalaman berusaha, besar keluarga, interaksi dengan sumber informasi, keikutsertaan dalam kursus dan pelatihan dan dukungan sarana dan prasarana. Semakin bertambah umur, nelayan cenderung semakin matang dan berpengalaman dalam kegiatan penangkapan, dan cenderung memperbesar anggota keluarga dengan lahirnya anak. Semakin bertambah umur, nelayan semakin cepat memasuki kategori umur kerja produktif, mereka cenderung merekrut keluarga lainnya untuk tinggal bersama demi kelanjutan usaha penangkapan. Pada kategori umur kerja sangat produktif dan kategori umur kerja produktif, kematangan fisik dan emosi berkembang dengan baik sehingga nelayan cenderung semakin baik berinteraksi dengan lingkungan, lebih matang dalam menerima inovasi dan pengambilan keputusan.

\section{- Pendidikan formal}

Sebagian besar $(53 \%)$ responden baru mencapai kategori pendidikan formal rendah. Pencapaian tingkat pendidikan formal tertentu tidak mempunyai hubungan dengan kemampuan nelayan mengaplikasikan motorisasi. Keterampil. 
an melayan yang mongesumakan motorisasi tidak diperoleh dari bangku sekolah, tetapi dituruskan melalui garis krtum unam atau herdasiokan pengalaman. Awak kapial leermotor biasamya diambil dari keluarga nelayan yang berpengalaman. karena diangeap mowarisi pengetahman. Ko. terampilan dan naluri molaut dari pendahulunya. Di samping itu. salrana pendidikan yange momadai belum tentu menjamin kualitas pendidilan seorang nelayan. karena biaya tinggi, lokasi yang terpusat di kota dan terbatasnya pergatulan merupakan hambatan bagi nelayan melanjutkan pendidikan ke jenjang yang lebih tinggi.

Hasil penelitian Manurung of el. (1989) memperlihatkan bahwa pendidikan penduduk yang bekerja sebagai nolayan, pengolah ikan, petani dan pedagang masih rendah. I!mummya mereka bekeria didasarkan pada pengalaman, misalnya jkut bekerja dengan orang tua sejak anak-anak.

\section{- Kursus dan polatihan}

Sebagian terbesar $(82 \%)$ responden bolum pernith ikut serta dalam kursus dan pelatihan. Keikutsertaan nelayan dalam kursus dan pelatihan cenderung rendah akibat jam kerja yang tidak teratur. Namun terdapat hubungan yang nyata antara keikutsertaan dalam kursus dan pelatihan dengan kemampuan mengaplikasikan motorisasi penangkapan.

Motorisasi penangkapan merupakan pekerjaan regu. Hasil penangkapan dan keselamatan nelayan dalam operasi dipertaruhkan pada saling ketergantungan dan kerja sama regu, karena itu pengetahuan dan keterampilan melaut yang dikuasai seorang nelayan melalui keikutsertaannya dalam kursus dan pelatihan diteruskan kepada awak lainnya secara bertahap lewat aktivitas penangkapan.

Mardikanto (1993) mengatakan tujuan kursus tidak hanya membekali sasaran dengan pengalaman belajar yang dapat digunakan memecahkan masalah atau memenuhi kebutuhan yang dirasakan, tetapi lehih banyak membekali pengalaman belajar yang dapat digunakan sasaran untuk melaksanakan tugas-tugas atau peran yang diterimanya, serta membekali pengalaman yang berguna bagi pemecahan masalah atau kebutuhan di masa mendatang yang mungkin belum dirasakan. Kursus dan pelatihan juga berhubuman nyata dengan umur. interaksi lengan sumber informasi. pengalaman usaha frnangkalpan dan dukungan pembinaan nelayan. Sumakin bertambah umur. scmakin matang fisik lan emosi sehingga nelayan cenderung semakin haik berinteraksi dengan lingkungan dan lebih siap dalam proses pengambilan keputusan. Scomakin lama menggeluti pekerjaannya, nelayan akan memiliki rentang waktu yang luas, schingga memperbesar peluang ikut serta dalam kursus dan pelatihan. Keikutsertaan dalam kursus dan pelatihan memberi motivasi kepada nelayan untuk selalu membekali diri dengan informasi. pengetahuan dan ketrampilan terbaru dari kegiatan pembinaan nelayan. Awak dari 23 unit kapal bermotor pernah mengikuti kegiatan kursus dan pelatihan. Sebagian besar awak yang mengikuti kursus dan pelatihan mempunyai tingkat aplikasi toknologi yang tinggi.

\section{- Pengalaman berusaha penangkapan}

Schagian besar (48\%) responden mempunyai pongalaman berusaha penangkapan dengan notorisasi pada kategori tinggi. Menangkap ikan dengan motorisasi merupakan pekerjaan keluarga, karena itu pengetahuan dan keterampilan melaut cenderung diwariskan menurut garis keturunan. Pengalaman berusaha penangkapan ternyata mempunyai hubungan yang nyata dengan kemampuan nelayan mengaplikasikan motorisasi penangkapan. Umumnya setelah tahun ke dua dan ke tiga nelayan mulai menyesuaikan diri (mental, pengetahuan dan keterampilan) dengan hal-hal menyangkut kegiatan penangkapan, menguasai emosi, menjalin kerja sama regu, menggunakan jaring dan pancing dengan benar, memahami tanda alam dan mengenal sifat objek tangkapan. Manurung (1989) mengatakan umumnya profil sebagai nelayan, apalagi sebagai pemimpin operasi penangkapan (juragan laut) lebih ditentukan oleh pengalaman, bukan pendidikan formal.

Pengalaman berusaha penangkapan juga berhubungan nyata dengan umur, keikutsertaan dalam kursus dan pelatihan. interaksi dengan sumber informasi, dukungan pembinaan nelayan, besar keluarga dan motif usaha. Semakin hertambah umur, nelayan cenderung memiliki rentang waktu yang luas dalam menjalini kegiatan penangkapan, serta memiliki kesiapan mental dan fisik untuk berinteraksi dengan 
lingkungan. Semakin lama menggeluti usaha motorisasi penangkapan, cenderung nelayan semakin memperbesar peluang keikutsertaan dalam kursus dan pelatihan, interaksi dengan sumber informasi dan terlibat dukungan pem. binaan nelayan.

Semakin banyak waktu menggeluti motorisasi penangkapan, nelayan cenderung semakin bijaksana menata kelangsungan hidup keluarga dengan mewariskan pengetahuan dan keteram. pilan melaut kepada angggota keluarga lainnya. Semakin lama nelayan menggeluti usaha motorisasi penangkapan yang mendukung kehidupan keluarga serta menjanjikan prospek yang baik, cenderung semakin menguat motif usaha, sehingga nelayan semakin terdorong mengaplikasikan motorisasi penangkapan. Semakin lama menekuni pekerjaan menangkap ikan dengan motorisasi, cenderung semakin tinggi aplikasi motorisasi penangkapan.

\section{- Besar keluarga}

Sebagian besar $(51 \%)$ responden mempunyai besar keluarga pada kategori sedang. Besar keluarga nelayan turut ditentukan oleh kepercayaan, adat, jumlah penduduk dan jenis mata pencaharian. Tradisi memiliki keluarga besar disebabkan pemahaman banyak anak banyak rezeki. rendahnya kompetisi terhadap lapangan kerja dan besarnya pendapatan dari bertani cengkeh.

Besar keluarga ternyata mempunyai hubungan yang nyata dengan kemampuan mengaplikasikan motorisasi penangkapan. Karena terbatasnya waktu di darat, nelayan membutuhkan tenaga keluarga lainnya untuk meperdagangkan dan mengolah hasil tangkapan. Anak yang cukup dewasa akan menggantikan orang tuanya jika berhalangan melaut agar pendapatan dan jatah ikan tangkapan tidak hilang. Nelayan yang tidak memiliki anak untuk melaut, cenderung merekrut laki-laki dewasa yang ada hubungan keluarga untuk tinggal di rumah sebagai pendamping keluarga dan sebagai pengganti melaut. Keadaan ini berakibat jumlah keluarga nelayan yang tinggal serumah cenderung besar.

Pollnac (1988) mengatakan cara hidup perilaku komunitas petani berbeda dengan komunitas nelayan. Perbedaan itu sebagai akibat dari sifat tempat pekerjaan dan keluarga Sebayak $35 \%$ nelayan yang diwawancarai dalan konsentrasi nelayan di San Miguel (Azoares) mengatakan bahwa mereka mempunyai nelayan lain dalam rumah tangganya, hanya $15 \%$ mengatakan bahwa mereka menangkap ikan tanpa sanak keluarga.

Besar keluarga juga berhubungan nyata dengan umur, pengalaman berusaha penangkap. an, interaksi dengan sumber informasi dan dukungan pembinaan nelayan. Semakin tinggi umur dan semakin berpengalaman seorang nelayan dalam mengaplikasikan motorisasi, cenderung semakin besar anggota keluarga. Besarnya kebutuhan untuk membiayai hidup keluarga, menyebabkan nelayan selalu berinteraksi dengan sumber informasi guna beroleh peluang berusaha, dan bagaimana menggunakan peluang tersebut untuk bersikap dan bertindak menentukan bentuk mata pencaharian yang akan digeluti.

\section{- Motif usaha}

Sebagian besar (59\%) responden mempunyai motif usaha pada kategori tinggi. Motif usaha ternyata mempunyai hubungan yang nyata dengan kemampuan nelayan mengaplikasikan motorisasi penangkapan. Hal ini ditunjang oleh terhentinya program pengembangan cengkeh dan ditinggalkannya usaha penangkapan dengan perahu dan kapal tanpa motor (tradisional) akibat dari besarnya permintaan untuk meningkatkan produksi, semakin luasnya kawasan penangkapan akibat terbatasnya stok ikan di perairan, meningkatnya kompetisi penangkapan dan besarnya harapan untuk memberikan jaminan bagi kelangsungan hidup keluarga.

Motif usaha juga berhubungan nyata dengan pengalaman berusaha. penangkapan dan inter. aksi dengan sumber informasi. Semakin lama nelayan menggeluti usaha perikanan tangkapan (yang mendukung kehidupan keluarganya serta menjanjikan prospek yang baik), cenderung semakin menguatkan motif usaha. Smith (1979) mengatakan faktor yang turut mempengaruhi perikanan rakyat adalah faktor sumber daya manusia, yang meliputi aspek psikologis yaitu motivasi.

Keputusan seseorang untuk terlibat dalam motorisasi penangkapan penuh dengan risiko, 
karena itu informasi tentang seluk-beluk penangkapan dengan motorisasi patut diketahui nelayan. Selain itu, kenyataan bahwa motorisasi penangkapan memiliki prospek yang baik mendorong nelayan selalu berusaha mendapatkan informasi terbaru tentang perkembangan motorisasi penangkapan. Semakin tinggi motif usaha, cenderung semakin tinggi aplikasi motorisasi penangkapan.

\section{- Interaksi dengan sumber informasi}

Sebagian besar $(48 \%)$ responden mempunyai interaksi dengan sumber informasi pada kategori sedang. Keadaan ini disebabkan Kecamatan Salahutu merupakan kawasan penangkapan ikan tertua di pulau Ambon, daerah transit kapal penumpang dan kapal angkut kebutuhan pangan penduduk dari dan ke Pulau Ambon, kawasan pendidikan, tempat praktek penangkapan mahasiswa Fakultas Perikanan dan Sekolah Usaha Perikanan serta memiliki pemancar radio dan televisi.

Interaksi dengan sumber informasi juga mempunyai hubungan yang nyata dengan aplikasi motorisasi penangkapan. Motorisasi merupakan pekerjaan beregu yang selalu menuntut adanya interaksi, maka interaksi antara nelayan maupun antara nelayan dengan pengusaha selalu terjaga. Pekerjaan menangkap ikan dengan motorisasi selalu dihadapkan pada persaingan pengunaan teknologi, serta mempunyai risiko keamanan dan keselamatan terhadap awak dan kapal bermotor, maka interaksi dengan sumber informasi selalu dipelihara.

Interaksi dengan sumber informasi juga berhubungan nyata dengan umur dan pengalaman berusaha penangkapan, serta keikutsertaan dalam kursus dan pelatihan. Di dalam kategori umur kerja sangat produktif dan kategori umur kerja produktif, kematangan fisik dan emosi herkembang dengan baik sehingga nelayan cenderung semakin baik berinteraksi dengan lingkungan dan lebih matang dalam proses pengambilan keputusan. sebagai tanggapan terhadalp berbagai ide. inovasi dan perubahan. semakin lama menekuni usaha motorisasi. seorang nelayan semakin berpeluang berinteraksi dengan sumber informasi.

Interaksi dengan sumber informasi juga berhubungan nyata dengan besar keluarga dan motif usaha. Semakin besar keluarga, cenderung semakin menguat motif usaha nelayan dan cenderung semakin meningkatkan interaksi mereka dengan sumber informasi yang bertujuan untuk mengembangkan usaha. Semakin tinggi interaksi dengan sumber informasi cenderung semakin tinggi aplikasi motorisasi penangkapan.

\section{- Dukungan sarana dan prasarana}

Sebagian besar $(51 \%)$ responden berpendapat dukungan sarana dan prasarana di Kecamatan Salahutu cukup memadai. Sarana dan prasarana tersebut terbagi atas sarana dan prasarana penangkapan, sarana dan prasarana penunjang penangkapan serta sarana dan prasarana penanganan hasil tangkapan.

Sarana dan prasarana penangkapan terdiri dari 16 unit motor tempel (purse seine) dan 20 unit kapal motor (pole and line) beserta kelengkapannya. Sarana dan prasarana penunjang penangkapan terdiri atas sebuah pelabuhan laut (berfungsi sebagai terminal kapal antar pulau), dua buah tempat berlabuh dan bongkar muat kapal penangkap ikan, sebuah BRI Unit Desa dan sebuah bank swasta, enam unit KUD dan tiga buah unit usaha non KUD, sebuah layanan bahan bakar milik PERTAMINA dan dua buah non PERTAMINA, empat buah unit layanan perbengkelan (servis dan onderdil) dan enam buah toko yang menyediakan berbagai kebutuhan penangkapan. Sarana dan prasarana penanganan hasil tangkapan terdiri atas lima cold storage. masing-masing satu di ibu kota kecamatan dan tiga di ibu kota propinsi. dua pasar rakyat di ibu kota kecamatan, satu pasar sentral di ibu kota kabupaten, serta tiga pasar rakyat dan satu pasar sentral di ibu kota propinsi.

Sarana dan prasarana perikanan di Kecamat an Salahutu telah tersedia sejak tahun 1970-an karena merupakan kawasan usaha perikanan tangkap tertua di Pulau Ambon. Ketersediaan sarana dan prasarana tersebut ditunjang kehijak. sanaan Pemerintah Daerah yang memberi kemudahan kepada nolayan dan pengusaha guna memperoleh dan memanfaatkannya. Ilal ini dilakukan mengingat potensi pengermbangan usaha motorisasi momiliki prospck yang baik. Tersedianya sarana dau prasarana yang disertai berbagai kemudahan untuk memperoleh daun memanfaatkannya morupakan faktor yang sangat mendukung aplikasi motorisasi penangkapan. 
Tidak tampaknya hubungan secara langsung antara dukungan sarana dan prasarana dengan aplikasi motorisasi penangkapan pada matriks korelasi lebih cenderung disebabkan oleh sebaran data yang kurang beragam.

\section{- Dukungan pembinaan nelayan}

Sebagian besar (54\%) responden mempunyai keikutsertaan pada kategori rendah dalam dukungan pembinaan nelayan. Tetapi dibandingkan keikutsertaan dalam kursus dan pelatihan yang banyak menyita waktu dan pesertanya terbatas, kegiatan pembinaan nelayan hanya membutuhkan waktu yang relatif singkat dan tidak membatasi jumlah peserta, sehingga nelayan dapat menyisihkan waktunya ikut serta, meskipun sebagian besar dalam frekuensi terbatas.

Frekuensi keikutsertaan nelayan dalam kegiatan pembinaan nelayan di Kecamatan Salahutu rata-rata empat kali dalam setahun. Keadaan ini disebabkan kemampuan Kepala Desa (Kades) menggerakkan partisipasi masyarakat.

Terdapat hubungan yang nyata antara dukungan pembinaan nelayan dengan aplikasi motorisasi. Dibandingkan dengan keikutsertaan dalam kursus dan pelatihan, keikutsertaan nelayan dalam kegiatan pembinaan nelayan lebih baik. Hasil penelitian menunjukkan setiap responden ikutserta dalam kegiatan pembinaan nelayan, walaupun berada pada kategori tingkat keikutsertaan yang beragam.

Dukungan pembinaan nelayan juga berhubungan nyata dengan umur, pengalaman berusaha penangkapan, interaksi dengan sumber informasi dan keikutsertaan dalam kursus dan pelatihan. Pada kategori umur kerja sangat produktif dan produktif. kematangan fisik maupun emosi berkembang dengan baik sehingga nelayan cenderung lebih terbuka dan tanggap terhadap berbagai ide, inovasi, perubahan dan perkem. bangan. Semakin lama waktu digunakan menggeluti usaha penangkapan dengan motorisasi, nelavan cenderung semakin berpeluang ikut serta dalam kegiatan pembinaan nelayan.

Dukungan pembinaan nelayan akan membuka isolasi mental nelayan untuk meningkatkan pengetahuan dan keterampilan. Usaha perikanan tangkap akan terus berkembang sesuai dengan kemajuan teknologi, dengan demikian nelayan cenderung mencari dan mendapatkan informasi serta cenderung ikut serta dalam berbagai kursus dan pelatihan.

Menurut Soewardi (1976), dalam melakukan kegiatan pembinaan terhadap petani-nelayan kecil tidak sekedar menyampaikan materi penyuluhan, tetapi yang lebih mendasar adalah membuka isolasi mentalnya, sehingga lebih mampu memanfaatkan sarana dan fasilitas yang tersedia.

\section{Keadaan dan Hubungan Aplikasi Motorisasi Penangkapan dengan Pendapatan Nelayan}

Sebagian kecil (22\%) responden telah mencapai kategori tingkat pendapatan besar (Tabel 4). Rataan pendapatan nelayan adalah $\mathrm{Rp}$ 370.000 per bulan, yang berkisar antara $R p$ 250.000 sampai Rp. 600.000 per bulan.

Aplikasi motorisasi penangkapan ternyata mempunyai hubungan yang nyata dengan pendapatan nelayan (Tabel 3). Pendapatan nelayan dari sebagian besar responden dikategorikan kecil. Dibandingkan dengan pendapatan dari pekerjaan menangkap ikan menggunakan alat tangkap seperti: pukat pantai, jaring angkat, jaring bobo dan perangkap ikan, atau pendapatan dari jenis pekerjaan lainnya seperti bertani, berkebun, beternak, konstruksi bangunan, buruh pelabuhan, montir atau berdagang kelontong, pendapatan nelayan dari motorisasi penangkapan lebih besar. Kenyataan tersebut menyebabkan seseorang cenderung akan memilih motorisasi penangkapan sebagai mata pencaharian.

Aplikasi motorisasi penangkapan mempunyai hubungan yang nyata dengan pendapatan nelayan, karena pendapatan nelayan bergantung pada satu jenis pekerjaan. Perhatian. tenaga dan waktu nelayan tercurah dan habis terpakai untuk mengaplikasikan motorisasi penangkapan. Nelayan tidak memiliki waktu luang memperoleh pendapatan dari mata pencaharian lainnya, karena itu mereka ditantang semakin baik mengaplikasikan motorisasi penangkapan jika ingin meningkatkan pendapatan.

Pendapatan sebagian besar responden dalam penelitian ini terlihat kecil, disebabkan oleh pembagian tanggung jawab yang dipikul saat melaut. Peluang memperbesar pendapatan diper- 
Tabel 4. Distribusi frekuensi tingkat pendapatan nelayan.

Table 4. Frequency distribution of fishermen income.

\begin{tabular}{lcc}
\hline $\begin{array}{c}\text { Kategori tingkat pendapatan nelayan } \\
\text { Level category of fishermen income }\end{array}$ & $\begin{array}{c}\text { Jumlah responden } \\
\text { (orang) } \\
\text { Number of respondent } \\
\text { (person) }\end{array}$ & $\begin{array}{c}\text { Persentase responden } \\
\text { Percentage of } \\
\text { respondent } \\
\text { (\%) }\end{array}$ \\
\hline Kecil (Low) (< Rp 375.000) & 99 & 55 \\
Sedang (Medium) (Rp375.000 - Rp 499.999) & 41 & 23 \\
Besar (High) (> Rp 499.999) & 40 & 22 \\
\hline Rataan pendapatan (Average of income) Rp 370.000 & \\
\hline Kisaran pendapatan (Range of income) Rp 250.000 - Rp 600.000 & 100 \\
\hline Jumlah (Total) & 180 & \\
\hline
\end{tabular}

oleh jika nelayan dapat mengemban tanggung jawab sebagai tanase atau lobe. Tanggung jawab sebagai tanase atau lobe selalu terbuka, karena banyaknya trip dalam sehari, bila tanase dan lobe yang bertugas berhalangan terlibat dalam kegiatan penangkapan, atau bila pengusaha menambah unit kapal bermotor. Tanggung jawab sebagai tanase dan lobe tergantung dari penge. tahuan, keterampilan, pengalaman dan kecakapan nelayan.

Pengetahuan, keterampilan, pengalaman dan kecakapan nelayan diperoleh melalui keikutsertaan dalam kursus dan pelatihan, memiliki sejumlah waktu melaut, ikut serta dalam kegiatan pembinaan nelayan dan memiliki kemampuan berinteraksi dengan sumber informasi. Melalui pengetahuan, keterampilan, pengalaman, dan kecakapan melaut tersebut, nelayan akan mampu mencapai kategori tinggi dalam mengaplikasikan motorisasi penangkapan, sehingga mereka akan berpeluang memperoleh pendapatan yang semakin besar. Kenyataan di atas me. nunjukkan bahwa aplikasi motorisasi penangkap. an mempengaruhi pendapatan nelayan. Semakin tinggi aplikasi motorisasi penangkapan, memberi indikasi semakin besar pendapatan nelayan (Tabel 5).

Tabel 5. Distribusi responden menurut analisis tabulasi silang antara tingkat aplikasi motorisasi penangkapan dengan tingkat pendapatan nelayan.

Table 5. Respondent distribution by cross - tabulation between motorization application level and fishermen income.

\begin{tabular}{|c|c|c|c|c|}
\hline \multirow{2}{*}{$\begin{array}{c}\text { Aplikasi motorisasi } \\
\text { penangkapan ikan laut } \\
\text { Motorization } \\
\text { Application of marine } \\
\text { fish capture }\end{array}$} & \multicolumn{3}{|c|}{$\begin{array}{l}\text { Pendapatan nelayan (\%) } \\
\text { Fishermen income (\%) }\end{array}$} & \multirow{2}{*}{$\begin{array}{l}\text { Persentase jumlah } \\
\text { responden } \\
\text { Percentage of } \\
\text { respondent number }\end{array}$} \\
\hline & $\begin{array}{c}\text { Kecil } \\
\text { Low }\end{array}$ & $\begin{array}{l}\text { Sedang } \\
\text { Medium }\end{array}$ & $\begin{array}{c}\text { Besar } \\
\text { High }\end{array}$ & \\
\hline Rendah (Lou(') & 6 & 1 & 1 & 8 \\
\hline Sedang (Medium) & 33 & 6 & 2 & 11 \\
\hline Tinggi (High) & 16 & 16 & 19 & 51 \\
\hline Jumlah (Total) & 55 & 23 & 22 & 100 \\
\hline
\end{tabular}




\section{KESIMPULAN DAN SARAN}

\section{Kesimpulan}

(1) Sebagian besar (51\%) responden telah mencapai kategori tinggi dalam mengaplikasikan motorisasi penangkapan ikan

(2) $47 \%$ responden bekerja pada kategori umur kerja sangat produktif, $53 \%$ responden baru mencapai kategori pendidikan formal kurang dari tujuh tahun, $82 \%$ belum pernah ikut serta dalam kursus dan pelatihan, $48 \%$ responden mempunyai pengalaman mengaplikasikan motorisasi penangkapan pada kategori tinggi, 51\% responden mempunyai besar keluarga pada kategori sedang, 59\% mempunyai motif usaha pada kategori tinggi, $48 \%$ responden mempunyai interaksi dengan sumber informasi pada kategori sedang, 51\% responden berpendapat ketersediaan dan kemudahan memperoleh sarana dan prasarana telah mencapai kategori tinggi, dan $54 \%$ responden mempunyai tingkat keikutsertaan pada kategori rendah dalam kegiatan pembinaan nelayan.

(3) Faktor internal dan faktor eksternal yang terdiri atas: umur, keikutsertaan dalam kursus dan pelatihan pengalaman berusaha penangkapan, besar keluarga, motif usaha, interaksi dengan sumber informasi, dukungan sarana dan prasarana, serta dukungan pembinaan nelayan ternyata mempunyai hubungan yang nyata dengan aplikasi motorisasi penangkapan. Semakin tinggi pengalaman berusaha, motif usaha dan interaksi dengan sumber informasi, memberi indikasi semakin tinggi aplikasi motorisasi penangkapan.

(4) Aplikasi motorisasi penangkapan di Kecamatan Salahutu mempunyai hubungan yang nyata dengan pendapatan nelayan. Semakin tinggi aplikasi motorisasi penangkapan, semakin tinggi pendapatan nelayan.

\section{Saran}

Supaya nelayan dapat mencapai kategori tingkat aplikasi tinggi disarankan:
(1) Mengingat terbatasnya jumlah nelayan yang menguasai pengetahuan dan ketrampilan melaut, maka pengusaha perlu mengikutsertakan nelayan dalam kursus dan pelatihan seperti: sertifikat kecakapan kelautan (SKK) 20 mil dan 100 mil, penguasaan dan penanganan mesin, alat tangkap dan alat bantu serta keterampilan melaut; yang dilakukan secara bergilir sehingga tidak merugikan waktu operasi penangkapan.

(2) Kegiatan pembinaan nelayan oleh Dinas Perikanan Propinsi Maluku, Universitas Pattimura Ambon, Perusahan Perikanan dan Lembaga Swadaya Masyarakat (LSM), lebih diarahkan membuka isolasi mental nelayan agar mau, tahu dan mampu mengatur perekonomian keluarga, membentuk kelompok nelayan dan membekali mereka dengan kemampuan memanfaatkan kredit, membentuk sikap positif nelayan terhadap kegiatan pelelangan ikan.

(3) Jumlah penyuluh perikanan dan frekuensi penyuluhan perikanan terutama mengenai motorisasi perlu ditingkatkan oleh Dinas Perikanan Propinsi Maluku.

(4) Pola pemilikan kapal bermotor dan alat tangkap melalui koperasi atau bank berbentuk pinjaman lunak kepada nelayan, perbaikan dan perluasan TPI serta pembangunan pasar ikan yang memadai sudah waktunya mendapat perhatian dari pemerintah daerah.

\section{DAFTAR PUSTAKA}

Biro Pusat Statistik, 1997. Survai sosial ekonomi nasional Propinsi Maluku 1997. Kantor Statistik Propinsi Maluku. 84 hal.

Black, J. A. dan D. J. Champion 1992. Metode dan masalah penelitian sosial. Diterjemahkan oleh Koeswara, E. Penerbit. P'T. Eresco, Bandung. 374 hal.

De Cecco, C. P. 1989. Educational psychology. Diedit oleh Joh P. De Cecco. Prantice IIall. Inc. Englewood Cliffs New Jersey.

Mardikanto, T. 1993. Penyuluhan pembangunan pertanian. Sebelas Maret University Press. 401 hal.

Manurung, V. T., A. Zulham dan E. Jamal. 1989. Penelitian potensi pengembangan desa pantai. 
Maluku dan Sumatera Utara. Pusat Penelitian Agro Ekonomi, Bogor.

Pollnac, R. B. 1988. Mengutamakan manusia di dalam pembangunan. Publikasi Bank Dunia. UI Press, Jakarta. 548 hal.

Singarimbun, M. dan S. Effendi. 1989. Metode penelitian survai. Penerbit LP3ES, Jakarta. 336 hal.
Smith, I. R. 1979. A Research framework for traditional fisheries. International Center for Living Aquatic Resources Managemant. Manila, Philippines.

Soewardi, H. 1976. Respon masyarakat desa terhadap modernisasi pertanian terutama Bali. Gajah Mada University Press, Yogyakarta.

Walpole, R.E. 1992. Pengantar statistika. PT. Gramedia Pustaka Utama, Jakarta. 516 hal. 